\title{
The Effects Of Child Abuse On The Victims And The Community - A Critical Analysis Of Amma Darko's Faceless And Lawrence Darmani's Grief Child
}

\author{
Cynthia Osei", Cecilia Addei* \\ Department of Liberal Studies, Kumasi Polytechnic, Kumasi, Ghana \\ English section, University of Mines and Technology, Tarkwa, Ghana
}

\begin{abstract}
This paper looks at the phenomenon of child abuse as presented in Amma Darko's Faceless and Lawrence Darmani's Grief Child. The work establishes the fact that the phenomenon of child abuse is prevalent in Africa in general, and in Ghana in particular. These two novels, afore-mentioned, have been discussed critically bringing out, inter alia, what child abuse is, the various types of child abuse, the causal factors and the effects of child abuse on both the abused child and the community as a whole. Mention has been made of possible preventive measures which ought to be put in place to curb this social menace.
\end{abstract}

\section{Introduction}

Child abuse has come very far, spreading its tentacles to every corner of the world. In fact, one can say that there are as many definitions of child abuse as there are people and groups of people who are ready and are trying to define it. Everyday, new occurrences or events go to add on to and consequently vary the already existing explanation or definition of child abuse. For this reason, therefore, no single, clear and accurate definition can be given to show what child abuse is. As given by the Cambridge International Dictionary of English, child abuse "is the act of making a child suffer physically, sexually or emotionally by either their parents or adults who should be taking care of them." The Encarta World of English Dictionary also defines child abuse as,[a] severe mistreatment of a child by a parent, guardian or other adult responsible for his or her welfare, including physical, violence, neglect, sexual assault or emotional cruelty. Finally, The Encyclopaedia of World Crime defines child abuse as, "any cruelty committed against a child [which] affects it mentally, morally or physically."

The common denominator for all three definitions above is that the child is helplessly at the mercy of the adult, namely, parent or guardian who apparently has the power and authority to make or mar, as it were, the entire being of the child. Again, the child who is obviously helpless is taken undue advantage of by no stranger but rather by a close relative who should even be providing it with care and attention. Indeed, it is sheer cruelty to the child and it may include any deliberate infliction of pain and suffering on the child and could be physical, emotional or sexual.

According to The New Encyclopaedia Britannica, before 1970 the term "child abuse" referred to physical maltreatment but has since then been expanded to include "... unreasonable physical violence and verbal abuse; the failure to provide proper shelter; nourishment, medical treatment or emotional support, incest and other cases of sexual molestation or rape; and the use of children in prostitution and pornography."

Physical abuse, sexual abuse, neglect and emotional abuse are the four forms of child abuse, which are identified by Dr. G. Deegener, in his presentation on child abuse in the International Encyclopaedia of the Social and Behavioural Sciences. He writes that deliberate acts of violence which result in injuries to children constitute physical abuse. Such acts include blows, beatings, injuring a child, punishing, strangling or even poisoning a child. Sexual abuse, in his view, refers to any sexual act that the child is made to endure against his or her own will or any action for which a child cannot make any firm decision due to his or her physical, emotional, mental or verbal immaturity. Acts like rape, fondling and sexual exploitation through child prostitution and pornography come under sexual abuse. (Deegeer, 2001:11).

Neglect as a form of child abuse is when a child is deprived of or denied his or her basic needs for affection and comfort due to an action or inaction on the part or a parent or guardian of the child. There is a school of thought that a single act of neglect may not necessarily result in child abuse. However, repeated acts of neglect can constitute child abuse. Acts such as the provision of insufficient food, proper care and inadequate medical attention can be described as neglect. A sterling example of neglect is seen in Darko's Faceless where Maa Tsuru is practically unwilling to protect her own children, Fofo and Baby T, from Poison's threats. Dr. Deegener goes further to group neglect into three types. He calls these groups physical, emotional and educational neglect. He explains the emotional form of child abuse to include any attitude or behaviour that may 
directly or indirectly interfere with a child's mental health or social development (Deegener,2001:13). It ranges from a simple insult to extreme forms of punishment. Indeed, emotional abuse has been established to have more lasting negative effects than the other forms of abuse on the child.

Child abuse comes about as a result of a number of causal factors. These factors are very commonplace and not far fetched. They range from individual, family, social and community levels. It is believed that people who tend to have a personal history of abusive childhood often grow into child abusers. Also the major factors that give rise to child abuse on the family front are believed to include unstable parentchild relationships and parental conflicts. There are schools of thoughts that poverty, unemployment, stress and lack of adequate social support structures are some of the social factors that give rise to child abuse. At the community level it has been observed that those communities, in which the growing child is exposed to a high rate of violence and aggression in his or her upbringing, become susceptible to having a high rate of child abuse. In another development, Dr. Eli Newberger, a medical doctor, writes in an article on child abuse that the causal factors of child abuse can be put into a number of theories and he goes further to classify these theories into two broad groups namely unitary theories and interactive theories (Newberger,1983:5). While Newberger's unitary theories can each be considered as an individual causal factor for child abuse, a number of unitary theories together constitute an interactive causal theory for child abuse. The under-listed constitute Newberger's unitary theories:

1. The psychoanalytic theory

2. The social learning theory

3. The environmental theory

4. The cognitive development theory

5. The labelling theory (Newberger,1983:8)

According to Newberger, the psychoanalytic causal theory of child abuse originates from factors like parental instability and conflicts. In his view adults who suffer from unstable mental health are more likely to abuse children theory (Newberger, 1983:10).

Under social learning theory, Newberger argues that the act of abusing children is a behaviour that is learnt and he goes on to say that parents and other adults who themselves suffer violent and abusive childhood have the tendency to abuse children. Such adults are likely to carry along with them unpleasant memories of their own childhood days which linger on their minds and cause them to abuse children. Amma Darko, for instance, illustrates this theory in her Faceless where the character Poison's abusive childhood at the hands of his step-father pushes him to inflict uncalled for abuse on street children who are younger than him, for example Fofo and her other friends.

Stressful social and environmental conditions like poverty, housing problems, unemployment and a relatively violent social atmosphere, in Newberger's view, constitute the environmental theory (Newberger, 1983:12). It has been explained further that families which suffer under stressful conditions like poverty are more likely to subject their young ones to various degrees of injustices. It is believed that adults under such conditions are not themselves in the right frame of mind to take good care of their children. Maa Tsuru's family in Faceless see most of their children on the streets because the parents themselves are unemployed and suffer under abject poverty. Also in Grief Child, under similar stressful conditions, Goma's only chance is to subject Adu to intense abuse.

Newberger's cognitive development theory suggests that child abuse occurs as a result of the fact that some parents or care providers believe that they are superior when it comes to their relationships with children (Newberger, 1983:13). This distorted belief comes about due to the fact that such parents and guardians do not understand their children and their own role as parents and guardians. Child abuse emanating from such egocentric parenting falls under this theory. In Faceless, for example, Poison's stepfather subjected him to abuse because of his own egocentric and distorted beliefs about child upbringing. This theory is further illustrated in Goma's actions in Grief Child where Goma's barrenness and inability to enjoy a wealthy lifestyle like her colleagues pushes her to visit her frustration on Adu.

The labelling theory directly identifies abusive behaviour with people in low economic situations. The theory argues further that even though child abuse is evident at all levels of the socio-economic ladder, it is more prevalent among those of low income status due to factors like unemployment and poverty. For instance, the setting of Darko's Faceless is the slum suburb of Sodom and Gomorrah, in Accra, where most children find themselves on the street because they are fatherless and their mothers are jobless and cannot take good care of them. Similarly, in Grief Child, Goma abuses Adu, the son of her own biological brother because she finds herself in a not too affluent position.

Dr. Newberger has further proposed the interactive theory of child abuse. According to his paper titled "Child Abuse: the current theory base and future research" published in the Journal of the American Academy of Child Psychology ${ }^{12}$, no single theory of his can give a holistic causal theory of child abuse. It is against this background that he has proposed the interactive theory, which according to him, should combine a number of 
unitary theories at a time in order to arrive at a more valid and convincing explanation for the factors that easily facilitate the abuse of children. For instance, Faceless portrays almost all the theories concurrently in order to identify the causes of child abuse.

A number of negative consequences are suffered by the abused child and these consequences may last for a short time or a long time and even for a life time depending on various factors which include:

i. $\quad$ The age and the developmental stage of the victim

ii. The length of the period of abuse

iii. The severity of abuse

iv. The relationship between the abuser and the abused

As has been mentioned earlier the abuser and the society also have their share of the negative consequences of the abuse. As we read Faceless, we observe that it is not only Baby $T$ who suffers from abuse but then eventually her death takes a toll on Maa Tsuru and Onco who eventually commits suicide. Also, Maame Broni who trades Baby $\mathrm{T}$ into prostitution does not have her peace of mind after Baby T's death. Again, all the children who find themselves on the streets become a liability not to their families alone but also to the entire nation. After all, are the effects of their viles like theft, prostitution, fights and drug abuse not felt by the community? They are indeed a threat to all and sundry.

The abused child can be affected right from his or her childhood days to his or her adulthood. Sometimes these nasty experiences tend to haunt the victims throughout their lives. As to their emotional effects, the child can be timid, experience low self esteem, anxiety and stress. The physical effects can range from injury, scars, health related problems or even death. Again, among school children, the abused ones are identified with low academic work, delinquency, truancy, teenage pregnancy and even suicide attempts.

It is noteworthy, however, that in spite of all the negative situations mentioned above, child abuse does not ultimately spell out total doom for the abused child. Dr. Newberger and other experts like him have suggested that recovery would be possible if only society would create a supportive environment for the abused child to recover from his or her bitter experiences. This view is shared by both writers as they illustrate it with their literary works. In Faceless, we see MUTE does exactly that for Fofo as Ofori and Becky do for Adu in Grief Child.

\section{The Presentation of Child Abuse in Faceless}

Faceless is Darko's third novel which was first published in 2003. It tells the unpleasant story of young children who are driven on to the streets by their own parents to battle it out and fend for themselves because these parents cannot simply discharge their duties as expected of them.

The plot tells the disturbing story of the complicated details of street and slum life in Accra while juxtaposing it with the life of a medium sized middle income Ghanaian family. The story is set in the slum area of Accra, precisely Sodom and Gomorrah. We read about Maa Tsuru who is virtually unemployed and who has already had four children with Kwei also unemployed and who one day, simply and completely "disappeared from their lives". Soon Maa Tsuru gets involved with Kpakpo, also unemployed and with whom she gives birth to two other children, Fofo and Baby ' $T$ '. Due to her inability to take care of her children Maa Tsuru consciously drives all her children on to the streets to fend for themselves.

The boys get mixed up with the hussles of life. The girls, Fofo and Baby ' $\mathrm{T}$ ' are helplessly at the mercy of macho men and street lords like Poison. Finally, Fofo gets 'rescued' by MUTE and Baby 'T' unfortunately, meets her untimely death.

In Faceless, Darko brings to the fore the plight of a good number of Ghanaian children who have no choice than to work under hazardous conditions in order to survive. The plot does not illustrate one specific type of child abuse; rather, there is the interplay of all the types of child abuse mentioned earlier on in this work. Various causes of child abuse are also seen in the story. Some of these causes include unemployment and poverty, unplanned pregnancies, irresponsible parenting, the breakdown of family and social values, ignorance and the ineffectiveness of some existing state functionaries. In the narrative certain life conditions which are stressful such as unemployment and poverty force parents and other adults to take certain drastic decisions which could be against their wishes.

Such decisions often weigh against their own children. In Faceless Maa Tsuru enjoys a relatively better life and takes better care of herself when she is employed in her aunt's kenkey business than when she is not employed. In the same vein Kwei and Kpakpo cannot take good care of themselves and their children due to unemployment which ultimately results in poverty. Since there is no secure job Maa Tsuru, Kwei, Kpakpo and Odarley's mother, among others, drive their own children on to the streets to fend for themselves only to be bullied and maltreated by the likes of Poison.

Kabria and Adade, on the otherhand, are employed and can cater for themselves and their children. All their children are not only in school but also can lay hands on a few luxuries here and there. 
Another cause of child abuse in Faceless is unplanned pregnancies. It is unplanned pregnancies that lead Maa Tsuru, Kwei and Kpakpo to behave the way they do. Maa Tsuru considers herself to be a woman like any other and therefore needs a man beside her. In her own submission:

...I am a woman and I was lonely ....

He gave me the right words.

He said, "I want to retire to bed with

you at night and wake up with you in

the morning. "It felt good...I had been

without a man since Kwei's final disappearance

from our lives...I felt like a woman, I needed to

be wanted by a man (p. 150)

Maa Tsuru somehow throws caution to the wind and goes ahead with her men, who do not take any precautions as well. She has four children with Kwei and two more with Kpakpo. All six pregnancies can be described as unplanned, since there is no preparation whatsoever for their birth

... "Maa Tsuru was still spending the nights with Kwei.

Neither of them took any precaution. They knew it could

happen. They assumed and hoped it wouldn't. Then it did ..."

Maa Tsuru and Kwei's second son is still crawling when she becomes pregnant for the third time. Kwei becomes angry and blames Maa Tsuru for it, as though it is all her fault and he plays no part at all in it. Kwei yells at Maa Tsuru:

How?.... Why? Why did you let it happen?

'Nonsense Maa Tsuru's uncle yelled back.'

Why didn't you ensure it didn't happen

by glueing an iron sheet around your loins? (p 150)

As mentioned earlier on, since all six pregnancies are unplanned, no proper care can be provided for the children. By the end of the novel four of the children have been pushed on to the streets.

Irresponsible parenting is another cause of child abuse as presented in Faceless. Maa Tsuru, Kwei, Kpakpo and other adults like Odarley's mother are portrayed as parents who are everything but responsible. They simply make the babies without taking the upbringing and the welfare of their children into consideration. Maa Tsuru simply allows Kpakpo to move in with her and her four children in the same room without taking cognisance of the fact that at least, it will inconvenience her two older sons. So when her sons are thus inconvenienced and leave home on a French leave, Maa Tsuru cannot be bothered:

...The first night with their new father in

the room, the boys did not sleep for a second

...Maa Tsuru could have gone to look for

her sons. She decided not to .... (p. 160)

Irresponsible parenting on the part of Maa Tsuru and her men starts from the birth of their children where arrangements are not even made to name their children.

Kwei and Maa Tsuru's first daughter ...

was never honoured with a Kwei family

name at birth. She went first by the name

'Tsuru's baby', which evolved ... to Baby ' $\mathrm{T}$ ' ...

When she gave birth to their second daughter ...

she ended up with the name Fofo. Someone

decided that she looked like an old relative by

that name. No one objected, so Fofo stuck. (p.155-156)

In effect these parents fail to live up to their responsibilities. They simply abandon the task of providing food, clothes, shelter, education and health care among others for their children.

Naa Yomo sums up who a good father is;

... A good man would never say to his child:

"there is no food, go out onto the street and find

some money for food". He would [rather] say:

"there is no food, so we'll all drink lots of

water and go to bed. Tomorrow is another day.

You will go to school and I will make sure there's

food to eat when you return home". (p.115-115)

Again it is irresponsible parenting which sends Poison on to the streets to eventually become a street lord. He lives with his mother and his step father and five siblings in a 'two by four room in a compound house in Accra' 
(p.198). His stepfather beats him often simply "for the play of it. His mother was compelled to look on helplessly. The one time she attempted to intervene, the belt was turned on her" (p. 198). And so Poison runs from home at the age of eight to hit the streets. Gradually he moves from one street attitude to the other, "By age fifteen ...He had made a mark and a name on the streets already" (p.199).

In contrast, Kabria plans her family and therefore practises responsible parenting. She lives in a roomy apartment where the parents have their own bedroom, then there is a girls' room occupied by her daughters Obea and Essie and then there is the boys' room occupied by Ottu her only son who sees himself as "Veeery special “ (p. 37). Their ages show that Kabria does proper parenting and plans her pregnancy for Obea is fifteen, Essie nine and Ottu is seven years old. They are all in school; Kabria takes them to school each morning in Creamy, her car, and picks them again after school. At home she assists them with their homework and housework is shared among them. The good mother that she is Kabria gets worried when she discovers that Obea is reading some literature on PPAG.

"I knew you saw it, Mum Obea cut in;

I knew you would go back to our room

to have a look." (p. 82)

The ineffectiveness of some of the existing state functionaries is a contributory factor which leads to child abuse. In Faceless we are made to see some of the realities that go on in some government offices. For instance the police officer rather than concentrate on efforts to regulate certain crimes and brutalities like child abuse sits at his desk to work lotto. It is difficult to blame him for the somehow negative attitude he shows towards the killing of Baby ' $\mathrm{T}$ ' because the provision of logistics for him to carry out his duties effectively is virtually non existent. The telephone line is out of order and vehicles in the yard are all out of use. Even his office cabinet has a problem and there is a gaping hole where there used to be a lock. In effect even if the officer comes to work, battle ready, there is nothing for him to work with.

From the foregoing it can be seen that Faceless portrays all four forms of child abuse namely: physical abuse, sexual abuse, emotional abuse and neglect. All four forms are evident in the narration. However, the emphasis is more on neglect. Some parents neglect their responsibility of providing for their children physically; emotionally and educationally. It is this neglect which drives the children onto the streets and puts them at the mercy of some wicked adults who also take undue advantage of the children's predicament and abuse them sexually, physically and emotionally.

Child abuse undoubtedly has consequences not only for the abused child but also for the abusers and the society at large. In Faceless Darko centres child abuse on neglect. Parental neglect drives the children out of their homes and onto the streets where they become exposed to a number of social vices. On the streets, Fofo and her friends are exposed to drugs, alcohol and adult movies. They also stand the constant risk of being raped. Poison who "...was an extremely shy boy; very soft spoken ..." (p.198) spends some time on the streets and soon ..." had mastered the intricacies ... He had no problem at all forming his gang (p.199). Young girls, under the direction of people like Maame Broni and Maame Abidjan, are lured into prostitution. Meanwhile behind prostitution lies the threat of these young girls contracting deadly sexually transmitted diseases such as HIV/AIDS.

Furthermore, child abuse creates psychological problems for the children in Faceless. They tend to feel unwanted and intimidated. For instance Poison admits that his life is definitely not on the right track and vows never to allow anybody else's to be on track. This is due to the extreme abuse he suffers at the hands of his step father. Also abused children often lose faith in others especially in adults. For example, Fofo finds it difficult to open up and divulge any information during her first few days at MUTE. It takes Fofo some time to learn to love, have faith and to be able to confide in Kabria and her colleagues.

In Darko's words:

... It seemed too much work for her

to develop some faith and trust in two groups

of people within the spate of a day.

After having lived without faith or trust for so

long on the streets, learning to trust and have

faith again was like a crawling child learning to walk ... (p. 98)

In Faceless child abuse does have some effects on the abusers as well. No matter the amount of joy or satisfaction which child abusers may derive as they abuse the children, it follows with a few exceptions that such abusers also suffer from guilt and depression, in the long run. Sometimes it may take a period of counselling before such abusers could be free.

For instance, in Faceless, Baby 'T"'s death causes a stir among some people. Onco suffers psychologically. His conscience disturbs him so much which invariably affects his productivity at work and he eventually commits 
suicide. Also Maame Broni starts having hallucinations after Baby ' $\mathrm{T}$ ' dies in her brothel. In her confession she says:

...I continued to see images ...Her spirit is seated inside my head like a chief in state. She is with me wherever I go ..." (p.230)

Maa Tsuru has no self confidence again after neglecting her children. The weight of her guilt makes her lock herself up in isolation from the rest of the family. As Kabria and her team at MUTE decide Fofo's fate, Maa Tsuru looks on helplessly.

The society outside also suffers some effects of child abuse both directly and indirectly. In Faceless even though Darko does not say so explicitly, it is implicitly evident that the society will abound in cases of teenage, unplanned and unwanted pregnancy with its attendant problems. Also girls like Fofo and Odarley stand the risk of contracting deadly sexually transmitted diseases. In Faceless many of the street children take to stealing. Poison starts stealing the moment he lands on the street

'within days, he had mastered in car

tape-deck thefts' p.198

In addition to stealing Poison becomes a rapist and a threat. Also, Kabria's first encounter with Fofo is when Fofo, dressed like a boy, steals her purse. The encounter is at the Agbogbloshie market when somebody shouts 'Get him! Don't let him go! He's got somebody's purse' p.70

It is worthy to note that these children often become a threat to the entire community. Poison does not steal from his relatives but from the citizenry. Fofo, Baby ' $\mathrm{T}$ ' and Odarley become thieves and a threat to the society. As Poison continues to rape young girls he may be encouraging the spread of the deadly HIV/AIDS disease. Again, valuable human lives may be lost as in the case of Baby ' $T$ '.

Since the negative effects of child abuse are suffered by the whole community as presented in Faceless it behoves on all and sundry to get on board to, at least, reduce the incidence of child abuse. The entire community becomes a dangerous place to live in due to the presence of social ills such as armed robbery.

In Mrs. Kamame's words:

The consequences of the phenomenon affect the entire society of which you are an integral part.

Ours is a society where family is the nucleus of our

culture. These children are growing up outside the culture of bonding to a family. The physical and psychological effect of this detachment is to render them easily susceptible to survival through jungle street tactics and foul means. Then me and you, who thought it was their problem alone, wake up one day to the rude realization that we have no choice but to share this same one society with them. (p.141)

\section{The Presentation of Child Abuse in Grief Child}

Like Darko's Faceless, Darmani's Grief Child discusses the types of child abuse as presented by the author and his view of possible factors which lead to child abuse. Darmani's presentation of the effects of child abuse on the abused children, care givers as well as the entire society have also been discussed.

The plot in Grief Child is divided into two parts. In the first part we are presented with the little village, Susa, where the villagers co-exist in harmony as they go about their farming activities. It is a typical Ghanaian village setting where people exhibit a sense of love, peace, hard work and brotherliness among others. This first part does not hint, in any way, at child abuse. Indeed it is obviously a closely knit society where each one is his brother's keeper. The plot, as presented in part one, centres on Nimo the husband, his wife Birago and their children Adu and Yaa who constitute Darmani's archetype of an ideal family. Generally parents in Susa nurture their children with love even as they ensure that their children grow and remain within the bounds of good discipline. In fact the author uses this first part of Grief Child to throw light on his view of how to discipline children properly. In this vein he contrasts Appiah's method of punishing children with Nimo's method. This is seen when Adu steals oranges from Appiah's garden. In Appiah's view the boy should be flogged mercilessly for:

Appiah looked round for a cane

With a big leap forward he dashed 
towards the unsuspecting boys. (p.48)

Nimo however holds a different view. He says to Appiah:
Appiah understand what I'm saying...
I'm not trying to protect my son - no
... In fact ... I've disciplined him
already ... when you want to
discipline a child, do so properly...
let him know that you're disciplining him.

Don't pin him down on the ground as though you want to kill him. (p.48)

Darman's view on proper discipline is further portrayed when Birago catches Adu as he eavesdrops on the conversation between Nimo and Goma. She disciplines him with a knock and a warning thus:

... Never, never eavesdrop

On elders when they're talking

in private. That's bad manners.

Never do that again. (p.42)

Darmani is hammering home the message that true discipline should be done out of love for the child and not merciless beating as Poison suffers from the hands of his step father in Amma Darko's Faceless.

Darmani's view is echoed in the biblical saying that God rebukes only those He loves as His children. The Bible encourages good training for children so that they will grow into responsible adults.

Train up a child in the way he should go:

and when he is old, he will not depart from it.

.(Proverbs 22:6,King James version)

In effect the first part of Darmani's Grief Child contains no hint of child abuse. It is only in the second part that the menace of child abuse surfaces. At the end of the first part Adu has lost both parents as well as his sister Yaa. The setting for part two is at Bauma where Adu begins a new chapter of his life with his aunt, Goma, in whose hands Adu suffers intense abuse. So Darmani's presentation of child abuse centres on orphans who are abused by their guardians and care givers who often turn out to be their family members. He goes ahead to suggest that children who find themselves in similar abusive conditions can turn their fates around and enjoy a comfortable adult life. In Darmani's presentation we see that when the family tie breaks down or is destroyed, children become exposed to abuse.

After Adu's family is struck by death in the second part of Grief Child, he is placed in the custody of his aunt, Goma who subjects Adu to merciless abusive conditions. Goma abuses Adu for several causes. One such cause is jealousy coupled with selfishness and bitterness. In her words to her brother Nimo:

All you do is tell the whole world you have a

great wife who supports you! You think it is

fair that you should neglect me and concentrate

on your children? You have not treated me well, do

you know that? (p.38)

These are Goma's words to her brother Nimo when she goes to visit him in the first part of Grief Child. Goma is jealous of her brother Nimo for several reasons, one of which is that she does not have the ideal family which her brother Nimo has. She is unable to cope with her childlessness and the fear of Ama's true identity haunts her. She goes ahead to blame her brother Nimo who is a herbalist and yet who cannot assist her to get her own child. Her jealousy of her brother's peaceful co-existence with his wife and children build up so much hatred, bitterness and anger which are visited on Adu when he is placed in her care. Here Darmani demonstrates clearly that in situations where guardians and other care providers are unable to deal with their own emotional problems they tend to abuse children placed in their care.

Again unemployment and poverty on the part of Goma make her subject Adu to intense abuse. Quite apart from the fact that Goma has a number of unsettled emotional problems at the time she takes on the responsibility of having to provide for Adu, there is also the suggestion that Goma has no regular source of income. At least there is no mention of what Goma does to earn a living apart from the indication that all that Goma has is a borrowed piece of land with which she sustains herself and Ama. Dr. Newberger's environmental theory is clearly seen here because one observes that the stress of having to feed, clothe and 
shelter Adu, in addition to herself and Ama, from her limited resources easily takes its toll on Goma and paves the way for child abuse to take place.

Therefore, Goma's situation is such that with little money to provide for her needs and those of Ama and Adu coupled with her anger and resentment towards her deceased brother, Nimo, she subjects Adu to underserved abuse. These two causal factors of child abuse in Grief Child go a long way to support Dr. Newberger's deduction that there is not a single causal factor for child abuse but rather, a number of factors combine to give way to child abuse.

Unlike Faceless, Grief Child does not entail all four forms of child abuse which are discussed in the introduction to this work. Darmani focuses instead on emotional abuse, physical abuse and neglect. Adu enjoys the benefit of having food, shelter and the opportunity of being in school. However, these incentives are woefully inadequate to keep him going on in life. In Goma's household therefore, Adu becomes the ultimate victim of the strained relationship between his father and his aunt (p.95). In contrast to what he enjoys when his parents and sister are alive, Adu does not enjoy any tender love and care from his aunt although the responsibility of carrying out most of the household chores rests upon him. Though his school uniform is tattered, Goma makes no effort to provide him with new ones or to mend his old clothes.

Again, Adu is subjected to physical abuse by Goma in the story. There are several instances of this physical abuse one of which is when he is beaten mercilessly by his aunt because he prevents his aunt from receiving money from Anane's mother in exchange for curing Anane of a snake bite. Indeed there are a number of instances in the novel when Adu suffers unwarrated emotional abuse from Goma. Also Goma uses harsh words on Adu as she throws heart piercing statements at the orphaned Adu. This is evident in the extract below:

'...you played your mother and your father! Where do you think I get soap for you to wash your clothes...' (p.95)

For a child who has just lost his loving parents, statements such as this are too harsh and will certainly cause emotional imbalance especially as they are from his own aunt.

Darmani goes ahead to demonstrate that apart from the abused child who suffers from the abusers, the society at large also suffer both directly and indirectly from child abuse. In Adu's case, for instance, he suffers both physically and emotionally from child abuse. Physically he loses weight and constantly falls ill when he is placed in Goma's care. Most of the time, he does not even have enough strength to enable him carry out his household chores. Nevertheless, these physical effects of child abuse on Adu even appear negligible when one considers the emotional and psychological effects child abuse has on him. His academic performance goes down drastically and he experiences so much dejection and neglect that he even contemplates suicide. Like Fofo and her friends in Faceless. Adu also ends up thinking and acting more maturely than his age mates. Darmani describes him as: 'A boy whose mind was older than boys of his age" (p.179)

Child abuse also has some effects on the care giver or the abuser in much the same way that it does affect the abused child. Goma already harbours some misgivings against her brother Nimo as she expresses these in her words:

'Since our father died, you've ignored me,

did you know that, Nimo?...

You have given all your attention to

your wife and your children' (p.38)

These are Goma's words to her brother when she visits him some time before his death. It is quite obvious that a greater percentage of Goma's anger and resentment for Nimo and his family is simply because she believes she has been neglected by Nimo and cut off from the benefits Nimo derives from the family. With so much resentment built up in her Goma simply subjects Adu to undeserved abuse when she is charged with the responsibility of caring for Adu after the death of his parents and sister. It is, however, surprising and somewhat inexplicable that instead of being triumphant over the extent of her control and authority over Adu, Goma rather becomes more miserable. Again Goma loses the respect of most people in the Buama community because of how she treats Adu. Some of the effects of child abuse on Goma are emotional because the abuse of Adu only makes Goma sink deeper in isolation and anger. This feeling of bitterness and loneliness is heightened when Appiah takes Adu away and Ama, Goma's source of joy, goes to live with Yeboah, her biological father. At this moment, Goma is left all alone with no close friends and relatives to keep her company. The question here is had Goma let go all this deep-seated anger and grudge against her brother, Nimo, and had she treated Adu well, then Adu would have been Goma's source of joy when Ama was taken away from her.

Child abuse also has some effects on the community. The Buama community in Grief Child does not have to deal with a neglected Adu as a street child the same way as the society in Faceless has to deal with neglected street children. However, every member of the Buama society shares in the burden of ensuring that 
Adu's life is saved from his aunt's abuse almost as soon as the plight of Adu becomes known to the bulk of the townspeople. Adu's rehabilitation therefore becomes a matter of concern to the entire Buama community. Also Appiah offers to return to Susa with Adu as his contribution to helping Adu out of his abusive experiences. Eventually, helpful adults such as Yeboah, Ofori and Beckie all get on board to help Adu triumph over his seemingly hopeless situation.

From the discussion above it is obvious that while an abused child may not necessarily end on the streets, all abused children eventually become the liability of the whole society. There is therefore, the need for everybody to get on board in order to reduce the rate of child abuse or better still, avoid the menace completely.

\section{A Comparative Analysis of Child Abuse in Faceless and Grief Child.}

It is evidently clear that both novelists succeed in presenting, very vividly, what child abuse is. Not only do they present the various forms and causes of child abuse but also they bring to light the consequences of child abuse on the abused child as well as the entire community. For both novelists, the emphasis is on neglect, where a child is abused as a result of being neglected by the parents or care providers. The setting for Darmani's Grief Child is Susa, a rural town. The protagonist, Adu, who turns out to be abused, does not suffer any abuse until he is orphaned. Darko's Faceless has an urban setting Accra, to be precise. In Faceless, Fofo and the other street children are not orphans. They are driven on to the street by their biological parents. In effect, both novelists portray that a child can be abused whether the parents are dead or alive. They both show some of the negative effects of abusing a child. By their analyses both writers show that the effects of abusing a child may range from consequences such as weight loss to death. Through their characters Fofo and Adu, Darko and Darmani demonstrate the psychological harm that could befall an abused child. They share similar views on the fact that regardless of the reasons that lead to child abuse, it is not only the abused child who suffers negatively but also, every member of the society or community suffers either directly or indirectly, from this social menace by having to bear some part of the responsibility of rehabilitation for the abused child. While both writers present the social vice of abused children in general ,Darmani tells the tale of an orphaned child while Darko concentrates her presentation on revealing the conditions of young abused girls who find themselves on the streets mostly due to acts of negligence on the part of their own parents. One wonders whether Darmani is suggesting that children whose parents are alive are not neglected and thus not abused; while Darko seems to be hinting that if parents are driving their own children on to the streets then one can imagine the degree of depravity and abuse that such children would suffer should their parents die. Again both writers identify and level criticisms against certain factors which are some of the root causes of child abuse. Tackling these factors from the root cause, according to both novelists, is the only way to either reduce the rate of child abuse or completely put an end to the phenomenon in Ghana. They therefore suggest practical solutions that could help rule out such factors that result in the abuse of children.

Darko identifies the over dependence of some women on men as one of the main causes of child abuse. In Faceless, therefore, she suggests that if women decide to be less dependent on their male counterparts and duly take on more responsibility for their own lives, then they would invariably be in a better position to adequately cater for their children. According to her, when this is done, it will at least be a step torwards moving most children away from neglect and other abusive conditions. A close examination of the mothers whose children suffer abuse in Faceless shows certain common characteristics including negligence and helplessness. Mothers like Poison's mother and Maa Tsuru virtually sit back and look on helplessly as their children are subjected to abuse. Poison, for instance, is abused physically and emotionally by his step father while Baby ' $\mathrm{T}$ ' is abused by Onco and Kpakpo. Some mothers like Tsuru and Odarley's mother are guilty of throwing their children into the streets to survive. As Darko writes about Poison's mother: “...His mother was always compelled to

look on helplessly. The one time she attempted to intervene, the belt was turned on her" (p.198)

Similarly, in describing Maa Tsuru's failure to cater for herself and for her children, Darko writes: "Maa Tsuru looked like a soul drowned in torpidity ... her world was dead. A life dissolved in absolute lethargy." (p. 42)

Darko criticises women like Maa Tsuru and challenges women like her to wake up from their 'slumber' and ensure a better livelihood for themselves and their children. She urges such women on to the task of educating themselves on relevant issues and the task of securing a decent and regular means of income for themselves as is the case with Kabria. A hypothesis can be made here; had Poison's mother been independent and had a regular means of income and had been well informed about the fact that she could report her husband's abusive behaviour to the relevant authorities, she surely would have had the courage to protect Poison from abuse by reporting his step father to such authorities. Again had Maa Tsuru been well informed about the use of some birth control methods, she might probably have used some of them in order to avoid unwanted pregnancy. Also, if she had had a regular and secure job, she would have had a better control over her affairs and would not have 
accepted Onco's money. Neither would she have felt compelled to send Baby 'T' away. She would probably have reported Onco to the right authorities had she been in the know of the existence of such state functionaries.

Another message Darko hammers home in Faceless is a call on women like Maa Tsuru to shake off their overdependence on men, the bulk of who, in Faceless, are indifferent about the well-being of the women who depend on them with their children. This Darko expertly does by juxtaposing Maa Tsuru and Poison's mother against women such as Kabria and the women in the blue Rasta Kiosk; both of whom are apparently above the "waters of poverty". In the case of the woman in the Rasta Kiosk for instance, even though the father of her child has absconded, she recognises the need to work to cater for her daughter and herself. She says to Kabria:

... I am here to work and make my

chop money for the day ... on top of

which I also need to save something to

cater for my Daughter. Her upkeep and

education is all upon my head (p.88)

For Darko, therefore, the issue is not whether a woman has a man beside her or not. Rather she is suggesting that if women are well informed about the pertinent issues that affect their lives and hold decent jobs which enable them to earn enough money, they will be in a better position to ensure that their children are adequately catered for. This will undoubtedly cause a reduction in the number of neglected children on our streets and additionally, result in a gradual decrease in child abuse in Ghana; even if it does not completely wipe out the menace from the Ghanaian community.

Again in Faceless Darko points out that women constitute a vital resource for the development of every nation because women possess the potential to move any nation forward. This she shows in her portrayal of the characteristics of Kabria, Vickie, Aggie and Dina as four independent, strong, confident and intelligent women who contribute their quota to help in the development of the society by working to support Dina's dream to have on alternative library source in the form of MUTE. In a combined effort these ladies also rise up to rescuing Fofo out of her deplorable conditions when they get to know of her plight. At this point Darko is sounding a note of caution that Ghana stands to lose her indispensable women in future if the young girls, in particular, are presently being neglected and exposed to extreme abusive conditions.

Darko's quest for the empowerment of women begins with young girls like Obea; who exhibits the potential to make bold decisions and draw intelligent conclusions about her life when she is given the right information on important issues about sex and HIV/AIDS. The suggestion is that essential and relevant education as well as awareness creation challenges young girls and women to do something productive with their lives and keep them away from falling prey to people who are likely to subject them to abuse.

For a very realistic approach, Darko implies in Faceless that it is not enough for women to make up their minds and take the initiative to provide for themselves and their children, but women also need the collaboration and support of reliable and responsible male counterparts like Sylv Poison to solve society's problems. For the four strong ladies of MUTE therefore, it is not just their education but rather their education as well as their readiness to take initiative coupled with the collaboration and support from Sylv Poison that enables them to unravel the mystery surrounding Baby ' $\mathrm{T}$ 's death. The suggestion being made here, by Darko is that both men and women need to pool their efforts together and to rise to the task of combating child abuse in Ghana.

Similarly, this call made by Darko in Faceless is only subtly re-echoed by Darmani in Grief Child. Here it is a woman, Goma, who becomes abusive because she is not financially and emotionally stable enough to support Adu, her nephew. Whereas Darko suggests that mothers should equip themselves and their children with access to the right information, Darmani's suggestion in Grief Child goes beyond the need for women to show love and care to children who are placed in their care. There is a clarion call on all members of the extended family, in particular, to show kindness and love to one another. The implication here is that when family members devote enough attention and show affection towards one another, a loving and secure family environment within which their children can live and grow up to become responsible adults will be realised. For instance in Grief Child, when Adu is taken away from his abusive aunt, Goma, and placed in an affectionate environment in his stay with Beckie and Ofori who provide him with a loving and secure family environment, he grows to be a responsible teacher to the benefit of his family and the entire community. If family members could sacrifice a little so as to guarantee a better future for the children in the family by providing support and a generally cordial atmosphere for their upbringing, Ghana will undoubtedly be well on her way to kicking child abuse out of her boundaries. 
In his introduction to Faceless, Kofi Anyidoho says:

The phenomenon of [child abuse] has become one of the most widely discussed social tragedies of our time. We are witnesses to a deluge of talk about the plight of these children from newspaper articles, to radio talk shows, television documentaries and elegant academic discussions. There are countless NGOs supposedly working for the interest of [abused children]. Many well-funded, well attended workshops and conferences have been covered on the subject. Even government claims to be doing its very best to tackle the problem. And yet, in spite of all these well publicized efforts, the problem only persists but also seems to be getting even more intractable. (p.20)

For many Ghanaians, however, the definition of child abuse may not be clear enough because in most Ghanaian homes children are expected to contribute their quota to helping with household chores. It is also an integral part of their training for children to perform such duties. In effect, apparently light jobs such as cleaning, washing utensils, helping with farm work among others have always remained the preserve of Ghanaian children.

In Grief Child, for example, Ama helps with house chores and yet she is not considered as an abused child. Again, back in Susa, Adu and Yaa as well as other children in the Susa community had their household and farm duties to perform and yet they are not also considered as being abused. The practice of making children work at home develops into child abuse when the work they are engaged in interferes directly or indirectly with their physical, mental and emotional health or well-being, with their education or when it costs them their lives. In 2003, a report on Ghana's human rights practices that was submitted to the American government, revealed that some children as young as seven were found working in informal sectors of the economy; sectors such as construction, mining, fishing and quarrying industries and also as domestic servants sometimes under quite hazardous conditions due to low income levels in Ghana. Darko's suggestion is that Ghanaians should not hide behind the tag of low economic status with its attendant problems to subject their children to abuse as is the case in Faceless.

In Darko and Darmani's analyses the solution to child abuse lies in its prevention. Yet, prevention does not come even from laws instituted by the government. The quotation above, from Kofi Anyidoho suggests that several laws and penalties could be passed at various fora including workshops and seminars organized by the government and yet these will prove futile if adults to not make personal commitment to curb child abuse on their own and in every way possible.

In Anyidoho's words instead of "[sowing] the seeds of human life, in quick repeated sessions of reckless ecstasy" (p.21) people who want to procreate should be prepared to shoulder the responsibility of catering for their children and also be ready to shield them from abuse. As Sylv Po says:

I am yet to hear of a child who asked to be born. If you are not

ready to love and cherish and provide adequately for a child,

why bring it into the world at all? (p. 141)

Once a child is born, the parents should be prepared to sacrifice all they can to ensure that the child is well taken care of. To these who are not ready to shoulder the responsibility of catering for a child, Sylv Po advises that:

If you are not ready, don't even begin to practice what could

result in the making of a child. Abstain! You can also visit the

office of the Planned Parenthood Association of Ghana. They

will assist you. (p. 141)

People should take precautionary measures against unwanted pregnancy and not to abandon their children. For, in Darko's words, the future promise of any nation can be directly measured by the present prospects of its youth. (p.102) In Faceless and Grief Child, Darko and Darmani respectively have cleverly suggested that bold steps must be implemented immediately to eliminate child abuse as its effects are not felt by the abused children and their immediate families only but also the entire society in which they live. This idea is echoed in Mrs. Kamame's submission on Sylv Po's show thus:

The consequence of the phenomenon affects the entire

society of which you are an integral part. Ours is a society

where the family is the nucleus of our children. These children

are growing up outside the culture of bonding to a family.

The physical and psychological effect of the detachment is

to render them easily susceptible to survival through

jungle street tactics and foul means. Then me and you

who thought it was their problem alone, wake up to the 
rude realization that we have no choice but to share

this same society with them ...(p.141)

Child abuse can be curbed entirely starting from within the immediate family setting of the growing child. Darmani's shows in his presentation that abused children can become beneficial to the society if they are rehabilitated and given the opportunity to move further in life. For instance, by the end of Grief Child, Adu, with the support of generous people like teacher Ofori and Beckie, becomes a teacher himself, just as Fofo in Faceless is finally on a smoother path to a brighter future. The question which comes to mind is why the other street children like Odarley and Poison do not get rehabilitated. The fact is that the abused child has a role to play in his or her own rehabilitation.

Children who are abused should have that personal determination and willingness to rise above their conditions by seeking help from the right quarters. Fofo seeks help from MUTE through Kabria and Adu seeks relief from abuse through teacher Ofori, Beckie and the leaders of Buama. Odarley on the other hand refuses to enter the premises of MUTE even when she is invited in by Fofo. In Poison's case the possibility of getting rehabilitated does not even cross his mind.

In reality, there are several instances in Ghana and elsewhere, where children who were rescued from child labour and abuse return to lead peaceful lives. There are NGO's like CARE NET GHANA, which provide facilities such as temporal shelter, counselling and rehabilitation for abused children in the Volta region. There are some abused children who choose not to access such facilities as well as others who are fortunate enough to be rescued and yet prefer street life where they control their own world.

\section{Conclusion}

In conclusion, Darko and Darmani are suggesting that the solution to the problem of child abuse lies in all Ghanaians being responsible enough to decide that no matter their social or economic status, they have to take bold steps and be more responsible for their lives and the lives of their children by either preventing unwanted pregnancies or bearing the full weight of catering for children once they are born. The two novelists also mention the need for collaboration and support between males and females in order to rescue abused children. There is a clarion call on all individuals, men, women, young and old, various organisations including churches, media houses, security organisations, NGOs, schools, government and the abused children themselves

to help reduce this phenomenon if not eliminate it completely. For in Anyidoho's introduction to Faceless, No seed grows into harvest joys without the planter's diligent labour of love. Until we come to this understanding as parents, as family, as community, we will forever stand condemned by the anguish in the eyes and voices of our children ... (p.21)

[1]. Darko, A. 2003. Faceless, Sub-Saharan publishers, Accra.

[2]. Darmani, L. 2005. Grief Child, Step publishers, Accra.

[3]. Deegener, G. 2001. "Child Abuse", International Encyclopaedia of the Social and Behavioural Sciences. $1^{\text {st }}$ ed. 3 vols. Cambridge University Press, UK. pp.11-13

[4]. Encarta World English Dictionary. London: Bloomsbury publishing PK, 1999

[5]. Newberger, E. 1983 "Child Abuse" Journal of the American Academy of Child Psychology, pp.5-13

[6]. The Encyclopaedia of World Crime, Criminal Justice, Criminology and Law Conference

[7]. The New Encyclopaedia Britannica, (2003), 15th ed., 3 vols, Chicago, USA. 